Kodifikasia : Jurnal Penelitian Islam, Vol 14, No. 01 (2020), 93-108

DOI : 10.21154/kodifikasia.v14i1.1898

ISSN : 1907-6371 (Cetak)

ISSN : 2527-9254 (Online)

\title{
THE IMPLEMENTATION Of ISLAMIC BOARDING SCHOOL CURRICULUM MANAGEMENT IN 4.0 ERA IN JEPARA REGENCY
}

\author{
Ali As'ad*, Purwanto**, Yusup Rohmadi***
}

\section{ABSTRAK :}

Penelitian ini bertujuan untuk mengetahui pelaksanaan kurikulum pesantren di Kabupaten Jepara di Era 4.0. Mengapa pesantren sudah menggunakan 4.0, tapi peserta didik tidak menguasai penggunaan media digital. Pondok Kabupaten Jepara ini adalah untuk mengetahui dinamika proses kebijakan pelaksanaan manajemen pendidikan di pesantren tersebut, untuk mengetahui pola manajemen yang dipraktekkan pengelola (kyai) dalam menggerakkan dan mengelola semua sumber daya di pesantren dan untuk mengetahui faktor penunjang dan faktor penghambat dalam kebijakan pengembngan manajemen pesantren sebagai tindak lanjut dalam peningkatan pengelolaan pendidikan pesantren. Penelitian ini di laksanakan di pondok pesatren memakai penelitian lapangan (field research) dengan metode kualitatif atau pendekatan deskriptif kualitatif, teknik pengumpulan data dilakukan dengan menggunakan telaah dokumentasi, wawancara dan observasi, analisis datang dengan tiga langkah yaitu: reduksi data, penyajian data, dan verifikasi data atau penyimpulan. Hasil penelitian dideskripsikan dengan dianalisis sehingga dapat menemukan menemukan teori serta pesan manajemen pendidikan madrasah pesantren (kyai) dengan manajemen pendidikan pesantren (kemenag). Hasil penelitian menunjukkan bahwa pengembangan merupakan suatu metode yang di gunakan untuk suatu hasil produk tertentu serta menguji keefektifan dari produk tersebut. Upaya untuk mengembangkan ilmu pengetahuan dan temuan temuan baru. Jadi penelitian ini adalah upaya untuk membuktikan mengembangkan dan menemukan bukti kongkret kebenaran sebuah model yang telah ada. hasil penelitian sangat mendukung dalam proses pembelajaran yaitu adanya fasiltas proyektor, laptop, audio, sehingga pada saat pembelajaran materi sangat didukung dengan fasilitas

\footnotetext{
* Universitas Islam Nahdlatul Ulama Jepara, email: aliasad@unisnu.ac.i.d

**Institut Agama Islam Negeri Surakarta Solo, email: akupur@yahoo.com

***Institut Agama Islam Negeri Surakarta Solo, email: yusup.rh@gmail.com
} 
tersebut, dan juga guru sangat terbantu fasilitas tersebut itu terbukti pada saat proses pembelajran guru menyampaikan materi menggunakan semua fasilitas tersebut sehingga peserta didik tidak jenuh dikelas

Kata Kunci: Manejemen kurikulum; Pondok Pesantren; Implementasi

\section{ABSTRACT :}

This study aims to: (1) explain the meaning of Islamic boarding schools; 2) explain the basis of religion, philosophical foundation and also social foundation Management culture of Islamic Boarding Schools; and (3) explain the curriculum development of Islamic boarding schools in Jepara. This research was carried out in several Islamic boarding schools in Jepara district. This study uses a qualitative method by emphasizing descriptive and problem analysis using a type of problem analysis (field research) that focuses on the analytical studies. So this research is an attempt to prove the development and finding concrete evidence of the truth of an existing model. The results of the study show that development is a method used for a particular product outcome and testing the effectiveness of the product. Efforts to develop new knowledge and findings. So this research is an attempt to prove the development and also find the real evidence and the truth of an existing model. The result of this research support the learning process such as the existence of projector facilities, laptops and audio, so that the learning process will be supported by these facilities, and also the teacher is greatly helped by these facilities as evidenced during the learning process the teacher delivers the material by using all of these facilities so that students not feel saturated in the class.

Keywords: Curriculum Management; Islamic Boarding School, Implementation

\section{INTRODUCTION}

Islamic boarding schools are the oldest Islamic educational institutions in Indonesia and grow together with the Islamic broadcasting period. Boarding 
schools are generally founded by clerics / kyai with independence, simplicity and sincerity. Educational institutions Islamic boarding schools before the 1960s are known as huts. This term according to Zamakhsyari Dhofier is known for dormitories or residences inhabited by santri mostly made of bamboo. Perhaps the word pondok comes from Arabic funduq which means dormitory or hotel. ${ }^{1}$

People who reject change will definitely be left behind because change is a necessity. Change can be gradual, it can also be systematic. One of the most obvious forms of change is globalization. Interaction between individuals, between communities, to between nations occurs quickly. Experts explain change as a time dimension. The connected world is only insulated by cyberspace. Change always gives a real sign and has a trace in human life. Changes in the phases of human life are marked by many things, one of which is a change in the industrial era. ${ }^{2}$

The basic principle of Industry 4.0 is the integration of machines, workflows and systems, by applying intelligent networks along the chain and production process to control each other independently. Hermann et al (2016) added, there are four industrial design principles 4.0. First, interconnection (connection), namely the ability of machines, devices, sensors, and people to connect and communicate with each other through the Internet of Things (IoT) or the Internet of People (IoP). This principle requires collaboration, security and standards. Second, information transparency is the ability of information systems to create virtual copies of the physical world by enriching digital models with sensor data including data analysis and information provision. Third, technical assistance which includes; (a) the ability of an aid system to support people by consciously combining and evaluating information to make the right decisions and solve urgent problems in a short time; (b) the ability of the system to support humans by performing tasks that are unpleasant, too tiring, or unsafe; (c) includes visual and physical assistance. Fourth, decentralized decisions which are the ability of virtual physical systems to make their own decisions and carry out tasks as effectively as possible. Simply stated, industry principle 4.0 according to Hermann et al (2016)

The industrial revolution began from industry 1.0, 2.0, 3.0, to industry 4.0. The industrial phase is the real change of existing changes. Industry 1.0 is characterized by production mechanization to support the effectiveness and efficiency of human activities, Industry 2.0 is characterized by mass

${ }^{1}$ Zamakhsyari Dhofier, Tradition of the Pesantren Study of the Life View of the Kyai and His Vision Regarding Indonesia's Future (Jakarta: LP3ES, 2011), 41.

2 Yahya M .Kes. M.Eng ,Era Industri 4.0 ,Tantangan dan Peluang Perkembangan Pendidikan Kejuruan Indonesia (2018), 14 
production and quality standardization, Industry 3.0 is characterized by mass adjustments and manufacturing and automation based robot flexibility. Industry 4.0 comes to replace industry 3.0 which is characterized by physical cyber and manufacturing collaboration (Hermann et al, 2015; Irianto, 2017) The term industry 4.0 originates from a project initiated by the German government to promote computerization of manufacturing. Lee et al (2013) explain, industry 4.0 is characterized by an increase in digitalization of manufacturing driven by four factors: 1) an increase in data volume, computational power, and connectivity; 2) the emergence of analysis, capabilities, and business intelligence; 3) the occurrence of new forms of interaction between humans and machines; and 4) improvement ${ }^{3}$

$\mathrm{KH}$. Abdurrahman Wahid or known as Gus Dur said that the pesantren is a place inhabited by santri. This statement is manifested by the significance of the characteristics of Islamic boarding schools as an integral educational environment as he likens it to a military academy. ${ }^{4}$ The existence of an Islamic boarding school's educational model has lived in the Indonesian culture for centuries ago and continues to this day. ${ }^{5}$

Islamic boarding school education has been recognized by western scholars such as Van Den Berg, Hurgronje and Geertz who are very influential in the formation and maintenance of the social, political, cultural and religious life of rural people throughout Indonesia ${ }^{6}$

Along with the times, education in Islamic boarding schools has also undergone a very rapid change and development in particular the curriculum and learning methods. Some Islamic boarding schools still maintain a typical education system of pesantren independently in both the curriculum and the learning and education process. ${ }^{7}$ Islamic boarding school is an educational institution that breathes Islam to understand, appreciate, practice Islamic teachings (tafaqquh fi al-din) by emphasizing the morality of religion as a guide to community life. ${ }^{8}$

\footnotetext{
3 Yahya M .Kes. M.Eng ,Era Industri 4.0 ,Tantangan dan Peluang Perkembangan Pendidikan Kejuruan Indonesia (2018), 14

4 Said Aqil Siradj and Et Al., Future Islamic Boarding School; Discourse on Pesantren Empowerment and Transformation (Bandung: Hidayah Library, 1999), 13.

5 Abdul Djamil, In Introduction to Educational Ideology of Islamic Boarding Schools in the Flow of Educational Ideologies (Semarang: Library of Rizki Putra, 2007), vii.

6 Dhofier, Tradition of the Pesantren Study of the Life View of the Kyai and His Vision Regarding Indonesia's Future, 38.

7 Directorate of Religious Education and Boarding School, Technical Guidelines for the Implementation of Compulsory Universal Basic Education Boarding School In Salafiyah (Jakarta: Ministry of Religion, 2003), 2.

8 Fery Diantoro, "Implementasi Manajemen Personalia Pendidikan Islam Berbasis Pengabdian Di Pondok Pesantren Wali Songo Ngabar, Jawa Timur," MANAGERIA: Jurnal Manajemen Pendidikan Islam 5, no. 1 (June 9, 2020): 137-154.
} 
This study aims to explain the meaning of Islamic boarding schools, explain the basis of religion and the philosophical foundation and social basis of the management culture of Islamic Boarding Schools, and explain the curriculum development of Islamic boarding schools in Jepara. This research is expected to be useful theoretically can provide support for the results of similar research and enrich the results of previous studies, as well as the development of theories about curriculum implementation in efforts to organize education, given the problem of such huts still haven't found an ideal meeting point in educational institutions huts in Indonesia optimally. Practically, the findings of this study can provide valuable information and input for researchers, for the government as input for the government to immediately issue policies on the importance of structuring the development of curriculum implementation in Islamic boarding schools.

Research was conducted using qualitative methods by emphasizing descriptive and analytical problems that use this type of problem analysis(fieldresearch), which focuses on the study of the analysis The cornerstone Model Development of Jepara Pesantren cottage management 4.0. Here are four grounds, namely philosophical foundation, foundation psychology, social cultural foundation, and the foundation of technological development.

\section{DISCUSSION}

\section{Definition of Islamic Boarding Schools}

Educational institutions Islamic boarding schools before the 1960s are better known as huts. This term according to Zamakhsyari Dhofier is better known as dormitories or residences inhabited by santri mostly made of bamboo. comes from Arabic funduq which means dormitory or hotel. ${ }^{9}$

While according to KH.Abdurrahman, boarding schools are defined as a place inhabited by santri. This statement shows the importance of the characteristics of pesantren as an integral educational environment. As he likens it to a military academy. ${ }^{10}$

The word is derived from the boarding school students who got the prefix pe-and the suffix -an meaning abode of the students. Professor Johns said that the term santri comes from Tamil, which means the teacher recites, while CC Berg argues that the word santri comes from the word

9 Dhofier, Tradition of the Pesantren Study of the Life View of the Kyai and His Vision Regarding Indonesia's Future, 38.

10 Siradj and Al., Future Islamic Boarding School; Discourse on Pesantren Empowerment and Transformation, 13. 
shastri derived from the Indian language which means holy books, religious books and books about science. ${ }^{11}$

The nature of human beings in the perspective of Islam is a perfect being (al-Tin: 4), ordered to worship (al-Dzariyat: 56), and naturally and its nature is sacred, as stated in the hadith: "Every human being is born in a sacred state (fitrah), it was his parents who made him Jewish, Christian and Majusi "(HR. al-Muttafaq 'Alaihi). From this point of view, non-Muslims in the perspective of Islam are humans who have the potential to reach the right religious level, because since their birth humans have been given the God of religious awareness (census numinis) namely the religion of nature or referred to as the religion of hanif (al- Rum: 30). The perspective of Islam towards humans reflects a different attitude of Islamic tolerance ${ }^{12}$

Indonesian law is a unique and complex law with a variety of perspectives because of the various entities within it. Multi-character and character society entities require the law to always adjust it 1 as Cicero said Ubi Societes Ibi Ius (where there is a community there is a law) 2. Law is understood as a complex system because of the existence of inseparable elements ${ }^{13}$

Every citizen has the right to get educational services, including Children with Special Needs (ABK), in accordance with the 1945 Constitution article 31 paragraph 1, and is affirmed in Law No. 20 of 2003 concerning the National Education System article 5 paragraph 1 and 2. Furthermore, the government explain again in article 32 paragraph 1 regarding special education (SLB). However, this raises the negative stigma of the community and the environment around those who have "shortcomings", thereby causing insecurity and feeling humiliated and excluded from the environment ${ }^{14}$

Terminologically, many restrictions given by experts, M. Arifin, for example, define pesantren as an Islamic religious education that grows and is recognized by the surrounding community. ${ }^{15}$

11 Siradj and Al., 13.

12 Hasan Bastomi, "Belajar Toleransi Di Pondok Pesantren Gontor Ponorogo," Edudeena 3 (2017): 53-67.

${ }^{13}$ Muhammad Shohibul Itmam, "INDONESIAN JURISPRUDENCE PERSPEKTIF AHMAD QODRI AZIZY (Indonesian Jurisprudence Ahmad Qodri Azizy's Perspective)," Justicia Islamica Jurnal Kajian Hukum Dan Sosial 16, no. 2 (2019): 367-94, https://doi. org/10.21154/justicia.v16i1.1639.

14 Husnul Khotimah, "PROBLEMATIKA PROSES PEMBELAJARAN PENDIDIKAN AGAMA ISLAM PADA SISWA TUNAWICARA DI SEKOLAH DASAR INKLUSI," Edudeene Vol. 3 No. 1 Januari 20193 No. 1 Ja (2019): 1-12.

${ }^{15}$ Ahmad Muthohar, Islamic Education Ideology; Islamic Boarding School Amid the Flow of Educational Ideologies (Semarang: Library Rizki Putra, 2007), 12.

Kodifikasia: Jurnal Penelitian Islam, Volume, 14 No. 1 Tahun 2020 
And in some literature it is stated that Islamic boarding schools are a modification of a Hindu religious education institution called mandala which is then given Islamic touches. Islamic boarding schools carry out several roles, mainly as educational institutions. If there is an Islamic education institution which also plays a role as a religious, scientific, coaching, development, and at the same time cultural symbol, then it is a boarding schoolthen that is the boarding school.

Islamic boarding schools, even though they are basically Islamic educational institutions, however, they have additional functions that are not less important than those of education. It is a means of information, cultural reciprocal communication with the community, a place for fertilizing community solidarity, and so on. ${ }^{16}$

Islamic Boarding Schools are the oldest Islamic educational institutions in Indonesia that grow together with the Islamic broadcasting period. Boarding Schools are generally founded by ulama / kyai with independence of simplicity and sincerity.

Islamic boarding schools are educational and da'wah institutions founded by Sheikh Maulana Malik Ibrahim in 1399 AD to spread Islam on Java. Furthermore, the person who succeeded in establishing and mating the Islamic boarding school is Raden Rohmat (Sunan Ampel). He founded the pondok pondok pondok first in yellow flower. Then he moved to Ampel Denta Surabaya and set up a boarding school there in the end he was known as Sunan Ampel. Then a number of Islamic boarding schools were erected by the students and their daughters such as Giri boarding school founded by Sunan Giri Demak boarding school by Raden Patah and Islamic boarding schools, Tuban Sunan Bonang. ${ }^{17}$

Islamic boarding schools, even though they are basically Islamic educational institutions, however, they have additional functions that are not less important than the education function. It is a means of information, cultural reciprocal communication with the community, a place for fertilizing community solidarity, and so on. ${ }^{18}$

Islamic boarding schools are systemic educational institutions. It contains goals, values and various elements that work in an integrated manner with each other and inseparable. The term system comes from the Greek "systema", which means a set of parts or components that are interconnected regularly and are a whole. Thus the education system is 6.

${ }^{16}$ Abdurrahman Wahid, Moves Tradition; Pesantren Essays (Yogyakarta: LKiS, 2001),

${ }^{17}$ Muhtarom HM, "Reproduction of Ulama in the Era of Globalization" (Publisher of Student Library, 2005), 106.

18 Wahid, Moves Tradition; Pesantren Essays, 6. 
the totality of the interaction of a set of educational elements that work together in an integrated manner and complement each other towards the achievement of the intended educational goals. ${ }^{19}$

The development of the world has given birth to a progress of the modern age fundamental changes in socio-cultural structures often hit various establishments. Therefore the pesantren education system must always make an effort to reconstruct understanding of its teachings in order to remain relevant and survive ${ }^{20}$.

The development for reconstruction has been understood. As is the rule of al-Muhafadzatu 'ala al-qadimi ash-shalih wa al-akhdzu bi al-jadid al-ashlah. This rule is a strong legality of all efforts to establish a model rekonstruksi.Kebebasan boarding school is a necessity, as long as it can not be separated from the frame al-ashlah (better).So also, when schools are required to reconstruct the world as a consequence of the progress of the modern world, the aspect al -ash be a keyword that must be held. ${ }^{21}$

The basic components that make an educational institution called pesantren, according to Zamakhsyari Dhofier, are five components including the following:

1. Kyai

Kyai are very diverse, including: ajengan, eagle in West Java; master teacher, master shaykh in Sumatra. Kyai is a charismatic figure who is believed to have extensive religious knowledge as a leader and owner of Islamic boarding schools. Kyai is a central figure who plans, organizes, and controls all implementation of educational activities in boarding schools. ${ }^{22}$

This dual position made it difficult for the clerics to become leaders of the pesantren; but the kyai are creative leaders who always succeed in developing pesantren in new dimensions; and the panoramic view of the compound-faced life of the pesantren today, is an indication of the genius creations of the clerics. ${ }^{23}$

2. Pondok

Pondok, a dormitory for santri, is a characteristic of the pesantren tradition, which distinguishes it from the traditional education system in mosques that develop in most Islamic regions in other countries. The

19 Wahid, 16.

${ }^{20}$ Siradj and Al., Future Islamic Boarding School; Discourse on Pesantren Empowerment and Transformation, 216.

${ }^{21}$ Siradj and Al., 217.

22 Muthohar, Islamic Education Ideology; Islamic Boarding School Amid the Flow of Educational Ideologies, 32.

${ }^{23}$ Muthohar, 32. 
surau education system in the Minangkabau or Dayah area in Aceh is basically the same as the cottage system, the different ones are just names. ${ }^{24}$

So it can be concluded that Islamic Boarding Schools are the oldest Islamic educational institutions in Indonesia that grow together with the Islamic broadcasting period. Boarding Schools are generally founded by ulama / kyai with independence of simplicity and sincerity.

\section{Management Foundation Islamic Boarding Schools}

Some experts have explained the principles or foundation of curriculum development. Nana Sudjana said there are three foundations, namely philosophical foundation, social cultural foundation and psychological foundation. ${ }^{25}$

Nasution mentions that there are four foundations, namely philosophical foundation, psychological basis, sociological foundation, and organizational foundation. ${ }^{26}$ Nana Syaodih Sukmadinata said four foundations, namely a philosophical foundation, a psychological foundation, a socio-cultural foundation and a foundation for the development of technological science. ${ }^{27}$ Omar Mohammed Al-Toumy Al-Syaibany also said four foundations, namely the foundation of religion, the foundation of philosophy, the foundation of psychology, and the foundation of sociology. ${ }^{28}$

From the opinions of experts above, it can be said that there are four foundations of curriculum development, namely:

1. The Foundation of Religion

This foundation of religion arises mainly from Islamic education thinkers, who generally have the establishment of all existing systems in society, including the Islamic education system, must lay the foundation of philosophy, goals, and curriculum in the teachings of Islam. in Islam, the main sources of religious teachings are the Qur'an and asSunnah, and other sources are ijtihad. From these sources education is developed, such as the formulation of educational objectives, materials and implementation strategies. ${ }^{29}$

${ }^{24}$ Dhofier, Tradition of the Pesantren Study of the Life View of the Kyai and His Vision Regarding Indonesia's Future, 81.

25 Nana Sudjana, Pembinaan Dan Pengembangan Kurikulum Di Sekolah (Bandung: Sinar Baru, 1991), 3.

26 S. Nasution, Curriculum Principles (Jakarta: Bumi Aksara, 2003), 14.

${ }_{27}$ Nana Syaodih Sukmadinata, Curriculum Development Theory and Practice (Bandung: Rosdakarya, 1997), 58.

28 Omar Mohammad Al-Toumy Al-Syaibani, Islamic Education Philosophy, ed. Hasan Langgulung (Jakarta: Bulan Bintang, 1979), 523.

${ }^{29}$ Al-Syaibani, 524. 
2. Philosophical foundation

The term of philosophy comes from the word philein which means love or love something. The sophia word means virtue or wisdom. It is thus clear that people who study philosophy are expected to be wise people in their behavior. ${ }^{30}$

Basic philosophy, this basis gives direction and compass to the purpose of education. With a philosophical basis so that the composition of the curriculum contains one truth, especially truth in the field of value values as a view of life that is believed from a truth. This is because a philosophy study is a value system, both related to the way of life and life, norms that arise from an individual group of people or a nation based on the in fluence of religion, customs and individual concepts about education $^{31}$.

3. Psychological

Basically, this basis considers the psychological stages of students related to physic a l development, maturity, physical, intellectual, language, emotional, social talent, individual needs and desires, interests and abilities. The psychological basis is divided into two types, namely: first the psychology of learning, the nature of the child can be educated, taught and given a number of material and knowledge. Besides that the nature of the child can change his attitude and can accept the norms of norms, can learn skills skills based on the ability of the child. Therefore how the curriculum provides learning opportunities for the child and how the learning process takes place, and in the circumstances of how the child gives the best results.

Child psychology, namely to get a situation of learning situations for children to develop their talents. Therefore it is natural for children to be a determining factor in curriculum development that takes place during the teaching and learning process ${ }^{32}$.

4. Socio-cultural

The definition of a social-cultural foundation is the importance of the social and cultural aspects that develop in the community as a reference in curriculum development. This departs from one premise that education is born from, by, and for society and culture. Here there is a harmonious reciprocal relationship between education, society and culture.

12.

${ }^{30}$ Imam Barnadib, Educational Philosophy (Yogyakarta: Adicita Karya Nusa, 2002), $12-13$.

${ }^{31}$ Muhammad Ali, Curriculum Development in Schools (Bandung: Sinar Baru, 1989),

32 Nasution, Curriculum Principles, 22-23.

Kodifikasia: Jurnal Penelitian Islam, Volume, 14 No. 1 Tahun 2020 
According to Nana Syaodih Sukmadinata, there are three important characteristics of education in relation to society.

a. Education contains value and gives value consideration. This is because education is directed at the development of children's personalities in accordance with existing values and expected by the community. Therefore the purpose of education contains value, then the content of education must contain values.

b. Education is directed at life in society. Education is not only for education, but preparing children for life in society. The young generation needs to know and understand what is in the community, have the skills to be able to participate in the community.

c. The implementation of education is influenced and supported by the local community as long as the education takes place. Community life affects the education process, because education is very inherent in people's lives. The educational process is part of the life process of society. The implementation of education requires support from the community, providing facilities, personnel, socio-cultural systems, politics, security and others. ${ }^{33}$

\section{Development of Islamic Boarding School Curriculum}

Models of curriculum development are an integral part of curriculum development studies, and are often considered to be a more important part of other dimensions, because the final result of the curriculum development process is a curriculum that is ready and feasible to use.

Curriculum development needs to be taken through certain steps systematically so that a good curriculum can be produced. Therefore curriculum development activities require a model that can be used as a theoretical basis for carrying out these activities. In curriculum development, the model is a theoretical review of the curriculum development process. ${ }^{34}$ In other words, the curriculum development model is theories about the steps of curriculum development.

According to Nana Syaodih Sukmadinata, explained that "The selection of a curriculum development model is not only based on its strengths and goodness and the achievement of optimal results, but also needs to be adapted to the education system and education management system adopted, and which educational concept models are used".

33 Sukmadinata, Curriculum Development Theory and Practice, 58-59.

${ }^{34}$ Burhan Nurgiyantoro, Dasar-Dasar Pengembangan Kurikulum Sekolah: (Sebuah Pengantar Teoretis Dan Pelaksanaan) (Yogyakarta: BPFE, 1988), 163. 
There are many models of curriculum development that have been put forward by education experts, especially the curriculum field. In the following description, it will be stated among these models that it is considered quite influential in the practice of making the curriculum today.

The curriculum development model model includes a curriculum development model according to Robert S. Zails, namely:

1. Administrative model (line-staff)

Thismodel is known as a staff line or top-down model. The work of this model is that education officials form a steering committee which usually consists of education supervisors, principles and core teaching staff. The steering committee is tasked with planning to provide guidance on policy outlines, preparing formulas for philosophy and general education goals. By completing the work they designate working group groups according to the needs of the members. Working groups generally consists of teaching staff and curriculum specialists. The task is to arrange specific objectives, contents and learning activities. The results of the work are revised by the steering committee. If deemed necessary and although this is rare, a trial will be held to examine the feasibility of its implementation. ${ }^{35}$

2. The Grass Roots Model

Development of curriculum components, one or all fields of study and all curriculum components. If the conditions have made it possible both in terms of teacher skills, facilities, fees and library materials, the model curriculum development grass roots will be better. This is based on the consideration that the teacher is the planner, executor and refiner of class teaching. Curriculum development that is grass roots may only apply to certain fields of study, but may also be used for similar fields of study in other schools, or in all fields of study in schools or other regions ${ }^{36}$

The stages of research and development development according to Borg \& Gall in Haryanti (2012) have 10 stages of model development, namely:

1. Research and information collecting, namely the study of literature relating to the problems studied, measurement of needs, small-scale research, and preparation to formulate research framework.

2. Planning, is the preparation of a research plan related to the problem, determining the objectives to be achieved at each stage, the steps of the research and if possible / needed to carry out a limited feasibility study;

3. Develop preliminary form of product, which is to develop the initial form of the product to be produced. Examples of developing learning materials, learning processes and evaluation instruments in learning.

${ }^{35}$ Rusman, Curriculum Management (Jakarta: Raja Grafindo Persada, 2011), 78-79.

${ }^{36}$ Rusman, 80. 
4. Preliminary field testing, which is conducting initial field trials on a limited scale, involving 1 to 3 schools, with a total of 6-12 subjects. In this step data collection and analysis can be done by interview, observation or questionnaire;

5. Main product revision, which is to make improvements to the initial product produced based on the results of the initial trial.

6. Main field testing, the main trial involving a wider audience. The results obtained from the trial were in the form of an evaluation of the achievement of the trial results (model design) compared to the control group.

7. Operational product revision, which is to make improvements / improvements to the results of a wider trial, so that the product developed is already an operational model design that is ready to be validated;

8. Operational field testing, which is a step in the validation test of the operational model that has been produced. Conducted in 10 to 30 boarding schools involving 40 to 200 subjects. Testing is done through questionnaires, interviews, and observation and analysis of the results.

9. Final product revision, which is to make final improvements to the model developed to produce the final product (final);

10.Dissemination and implementation, dissemination of products / models developed to the general public / community, especially in education ${ }^{37}$

The development of Islamic boarding schools has followed the changes of the present time, which gave rise to fundamental changes in the socio-cultural structure with the dynamics of modernization, not least in the pesantren education system which always seeks to reconstruct understanding of the teachings of the teachings in order to stay relevant and survive. ${ }^{38}$

Reconstruction in the development of Islamic boarding schools has been understood as explained in the fiqhiyah rules "Al-Muhafadhotu alal qodimi sholih wal akhdzu bil jadil al alashlah" This rule is a strong legality for all reconstruction efforts for the development of Islamic boarding schools. is a necessity, provided that it is inseparable from the frame of al-ashlah (better). Similarly, when Islamic boarding schools reconstruct in development as a consequence of the progress of the modern world, the aspect of al-ashlah becomes a key word that must be held. ${ }^{39}$

${ }^{37}$ Sri Haryati, "Research and Development (R \& D) as One of the Research Models in the Field of Education," Journal of Research And Development (R E D) 37, no. 1 (2012).

38 Siradj and Al., Future Islamic Boarding School; Discourse on Pesantren Empowerment and Transformation, 216.

39 Siradj and Al., 217. 
Development of a curriculum that can be applied in its implementation. The application of the model model should be based on constant factors so that review reviews of the model models discussed can be expressed consistently.

\section{CONCLUSION}

Jepara district Islamic boarding school in accordance with the vision and mission of the pesantren itself 1 . Religious foundation 2. philosophical basis 3. Psychological bases 4. Social bases Culture and Output and Input approaches have a level of importance of two levels lower than output.

The expected output of the model of management development curriculum boarding school in Jepara, there are four kinds, namely the achievement of academic knowledge of religion, achievement of academic knowledge generally, achievement skills or life skills and achievement in the field of non-academic

Input boarding school there are five kinds as follow, 1. the policy goal and clear quality objectives 2 . available and ready resources 3 . highly competent dedicated staff and morality 4 . have high achievement expectations 5 . focus on santri customers

Development is a method used for a particular product outcome and testing the effectiveness of these products. Efforts to develop knowledge and new findings. So this research is an attempt to prove developing and finding concrete evidence of the truth of an existing model. 


\section{REFERENCE}

Ali, Muhammad. Curriculum Development in Schools. Bandung: Sinar Baru, 1989.

Al-Syaibani, Omar Mohammad Al-Toumy. Islamic Education Philosophy. Edited by Hasan Langgulung. Jakarta: Bulan Bintang, 1979.

Barnadib, Imam. Educational Philosophy. Yogyakarta: Adicita Karya Nusa, 2002.

Bastomi, Hasan. "Belajar Toleransi Di Pondok Pesantren Gontor Ponorogo." Edudeena 3 (2017): 53-67.

Dhofier, Zamakhsyari. Tradition of the Pesantren Study of the Life View of the Kyai and His Vision Regarding Indonesia's Future. Jakarta: LP3ES, 2011.

Diantoro, Fery. "Implementasi Manajemen Personalia Pendidikan Islam Berbasis Pengabdian Di Pondok Pesantren Wali Songo Ngabar, Jawa Timur." MANAGERIA: Jurnal Manajemen Pendidikan Islam 5, no. 1 (June 9, 2020): 137-54. https://doi.org/10.14421/manageria.2020.51-08.

Djamil, Abdul. In Introduction to Educational Ideology of Islamic Boarding Schools in the Flow of Educational Ideologies. Semarang: Library of Rizki Putra, 2007.

Haryati, Sri. "Research and Development (R \& D) as One of the Research Models in the Field of Education." Journal of Research And Development (R E D) 37, no. 1 (2012).

HM, Muhtarom. "Reproduction of Ulama in the Era of Globalization." Publisher of Student Library, 2005.

Itmam, Muhammad Shohibul. "INDONESIAN JURISPRUDENCE PERSPEKTIF AHMAD QODRI AZIZY (Indonesian Jurisprudence Ahmad Qodri Azizy 's Perspective)." Justicia Islamica Jurnal Kajian Hukum Dan Sosial 16, no. 2 (2019): 367-94. https://doi.org/10.21154/ justicia.v16i1.1639.

Khotimah, Husnul. "PROBLEMATIKA PROSES PEMBELAJARAN PENDIDIKAN AGAMA ISLAM PADA SISWA TUNAWICARA DI SEKOLAH DASAR INKLUSI." Edudeene Vol. 3 No. 1 Januari 20193 No. 1 Ja (2019): 1-12. 
108 | Ali As'ad, Purwanto, Yusup Rohmadi

Muthohar, Ahmad. Islamic Education Ideology; Islamic Boarding School Amid the Flow of Educational Ideologies. Semarang: Library Rizki Putra, 2007.

Nasution, S. Curriculum Principles. Jakarta: Bumi Aksara, 2003.

Nurgiyantoro, Burhan. Dasar-Dasar Pengembangan Kurikulum Sekolah: (Sebuah Pengantar Teoretis Dan Pelaksanaan). Yogyakarta: BPFE, 1988.

Rusman. Curriculum Management. Jakarta: Raja Grafindo Persada, 2011.

School, Directorate of Religious Education and Boarding. Technical Guidelines for the Implementation of Compulsory Universal Basic Education Boarding School In Salafiyah. Jakarta: Ministry of Religion, 2003.

Siradj, Said Aqil, and Et Al. Future Islamic Boarding School; Discourse on Pesantren Empowerment and Transformation. Bandung: Hidayah Library, 1999.

Sudjana, Nana. Pembinaan Dan Pengembangan Kurikulum Di Sekolah. Bandung: Sinar Baru, 1991.

Sukmadinata, Nana Syaodih. Curriculum Development Theory and Practice. Bandung: Rosdakarya, 1997.

Wahid, Abdurrahman. Moves Tradition; Pesantren Essays. Yogyakarta: LKiS, 2001. 